\title{
Analisis Kualitas Website pada PT.DAW Menggunakan Metode Webqual 4.0 dan Importance Performance Analysis (IPA)
}

\author{
Marlivye Makapedua ${ }^{1}$, Alexander Tompunu ${ }^{2}$, Green Arther Sandag ${ }^{3}$ \\ 1,2,3 Sistem Informasi, Fakultas Ilmu Komputer, Universitas Klabat, \\ Jl. Arnorld Mononutu, Airmadidi - Minahasa Utara, Manado, Sulawesi Utara \\ ${ }^{1}$ s21610420Qstudent.unklab.ac.id \\ ${ }^{2}$ s21610483estudent.unklab.ac.id \\ ${ }^{3}$ greensandag@unklab.ac.id
}

\begin{abstract}
Abstrak
Seiring dengan perkembangan zaman, teknologi informasi menjadi salah satu faktor penting dalam kemajuan disegala aspek. Media website sudah menjadi sarana yang digunakan dalam perusahaan dimana website tersebut digunakan dalam hal penyampaian informasi kepada customer dan employees. Website PT. Daya Adicipta Wisesa sebagai acuan masyarakat luar maupun pihak perusahaan untuk mendapatkan informasi yang berkualitas berdasarkan persepsi dari pengguna akhir dengan melakukan evaluasi. Website PT. Daya Adicipta Wisesa perlu dilakukan evaluasi untuk mengukur dan meningkatkan kualitas layanan dengan menggunakan metode WebQual 4.0 yang didalamnya terdiri dari tiga jenis variable yaitu usability, information quality, service interaction dan metode Importance Perfromance Analysis (IPA). Hasil akhir dari nilai rata-rata keseluruhan untuk nilai performance adalah 3.674, untuk nilai importance adalah 4.423. Untuk hasil rata-rata dari nilai kesenjangan (GAP) adalah -0.734, dan hasil rata-rata dari nilai kesesuaian adalah $84.23 \%$. Untuk hasil dari analisis kuadran, terdapat 4 kuadran dan kuadran yang menjadi prioritas utama dalam melakukan perbaikan terdapat 3 atribut. Hasil dari analisis kuadran untuk prioritas utama adalah: Website daw tidak mempunyai desain yang menarik, informasi yang ada pada website daw tidak akurat.
\end{abstract}

Kata kunci: WebQual 4.0, Importance Performance Analysis, Website PT. Daya Adicipta Wisesa

\section{Analysis of Website Quality at PT. DAW Using Webqual 4.0 and Importance Performance Analysis (IPA)}

\begin{abstract}
Along with the times, information technology has become one of the important factors in progress in all aspects. Website media has become a tool used in companies where the website is used in terms of delivering information to customers and employees. PT. Daya Adicipta Wisesa website as a reference for the outside community or the company to get quality information based on the perception of the end user by conducting an evaluation. PT. Adicipta Wisesa power needs to be evaluated to measure and improve service quality using the WebQual 4.0 method, which consists of three types of variables, namely usability, information quality, service interaction and the Importance Performance Analysis (IPA) method. The final result of the overall average value for the performance value is 3,674 , for the importance value is 4,423 . For the average yield of the gap value (GAP) is -0.734 , and the average yield of the conformity value is $84.23 \%$. For the results of the quadrant analysis, there are 4 quadrants and the quadrant is the main priority in making improvements there are 3 attributes. The results of the quadrant analysis for the main priority are: The daw website does not have an attractive design, the information on the daw website is not accurate
\end{abstract}

Keywords: WebQual 4.0, Importance Performance Analysis, Website PT. Daya Adicipta Wisesa

\section{PENDAhUluan}

Seiring dengan perkembangan zaman globalisasi atau bisa juga disebut zaman modernisasi, teknologi informasi dan komunikasi telah membuat informasi begitu mudah untuk diakses melalui berbagai sarana saluran komunikasi [1]. Berdasarkan data dari hasil studi pada Polling
Indonesia yang bekerja sama dengan Asosiasi Penyelenggara Jasa Internet Indonesia (APJII), pada 2018 jumlah pengguna internet di Indonesia sudah mencapai 171,17 juta jiwa[2]. Meningkatnya jumlah pemakai internet di Indonesia membuat teknologi telah menjadi kebutuhan dasar manusia, dari orang tua hingga anak muda dimana setiap orang sudah menggunakan teknologi 
dalam kesehariannya, salah satu contoh kemajuan teknologi informasi telah membantu manusia dalam berbagai hal yang memudahkan aktivitas kesehariannya seperti dari cara berkomunikasi secara bebas, tanpa dibatasi oleh ruang, jarak dan waktu [3]. Website atau World Wide Web (WWW) juga membantu manusia dalam menemukan semua jenis informasi yang berkaitan dengan bidang mereka dan untuk menggunakan bentuk media masa website harus membutuhkan jaringan internet untuk bisa mengaksesnya, Website yang baik adalah website yang diminati oleh penggunanya [4].

Di zaman modern saat ini, teknologi informasi menjadi salah satu faktor penting dalam kemajuan disegala aspek. Media website ini sudah menjadi sarana yang digunakan dalam perusahaan dimana website tersebut digunakan dalam hal penyampaian informasi kepada para customer dan employees selain itu dengan adanya website perusahaan akan terlihat lebih professional karena perusahaan akan lebih dipercaya oleh pelanggan dengan keamanan informasi, data dan lainnya. Dengan adanya website, perusahaan mempunyai seorang pekerja yang bekerja 24 jam yang memberikan informasi kepada pengunjung. Website perusahaan perlu mendapat perhatian dalam menjaga konsistensi kualitasnya dari aspek penilaian website untuk menjadi lebih baik. Oleh karena itu peningkatan kualitas layanan berbasis website harus dilakukan untuk meyakinkan pengguna agar tetap menggunakan layanan website yang ada [5].

PT. Daya Adicipta Wisesa adalah perusahaan yang bergerak di industri otomotif sebagai Main Dealer Sepeda Motor Honda dan suku cadang asli Sepeda Motor Honda untuk wilayah Sulawesi Utara, Gorontalo, dan Maluku Utara. PT. Daya Adicipta Wisesa memiliki 3 core bisnis yaitu: 1. Penjualan Unit yaitu H1, 2. Pemeliharaan yaitu H2, 3. Penjualan Suku Cadang yaitu H3. Berdasarkan keputusan dari perusahaan induk PT. Daya Adicipta Wisesa yaitu Triputra Group, serta didukung visi dan misi yang telah ditetapkan, perusahaan ini menerapkan pemanfaatan TI dalam proses bisnis yang dijalankan. Website PT. Daya Adicipta Wisesa memberikan informasi kepada pelanggan mengenai produk motor cub, sport matic, sparepart motor, dealer, ahass dan juga tracking STNK, dalam website tersebut pengunjung bisa melihat lowongan pekerjaan dan medaftar secara online [6].

WebQual merupakan metode yang digunakan untuk mengukur suatu kualitas dari website yang disusun dalam tiga dimensi kualitas, yaitu usability, information quality dan service interaction [6]. WebQual telah dikembangkan sejak tahun 1998 yaitu WebQual versi 1.0 yang menekankan pada kualitas informasi dari suatu website, kemudian WebQual ini ditingkatkan pada versinya yang ke 2.0 dengan tambahan pada kualitas intereaksi pengguna. Pada WebQual versi 3.0 suatu kualitas website dibagi dalam 3 bagian, yaitu site quality, information quality, dan service interaction quality, yang akhirnya pada versi 4.0 site quality diubah menjadi usability karena lebih menekankan pada sisi persepsi dari pengguna dan bukannya sisi dari pengembang[7].

Menilai dimensi kualitas dari WebQual terhadap suatu website memerlukan pengukuran Importance
Performance Analysis (IPA) yang digunakan untuk mengukur dan menilai suatu tingkat kepuasan berdasarkan pada tingkat kepentingan (importance) dan kinerja (performance). WebQual dan IPA berkaitan karena IPA akan melakukan analisis dari kesenjangan (gap) dari semua atribut dalam WebQual 4.0 yang cara kerjanya adalah membandingkan kinerja dari apa yang dirasakan sekarang dan apa yang diharapkan[8][9][10].

Tujuan penelitan ini adalah untuk mengetahui penilaian secara keseluruhan dari pengguna akhir terhadap pengunaan Website PT. Daya Adicipta Wisesa, dan mengukur kualitas Website PT. Daya Adicipta Wisesa berdasarkan variabel dimensi WebQual 4.0 yaitu usability, information quality, service interaction dan importance performance analysis terhadap kepuasan pengguna.

\section{Metode PenELITIAN}

Metode penelitian pada penelitian ini akan membahas tentang populasi, sampel penelitian, rumus yang digunakan, desain penelitian, metode penelitian, studi pustaka, instrument pengumpulan data, perancangan kuesioner, prosedur pengumpulan data, serta metode analisis data, prosedur pengumpulan data pada PT. Daya Adicipta Wisesa.

\section{A. Lokasi Penelitian}

Pada penelitian ini, lokasi yang dipilih untuk pengumpulan data yaitu di PT. Daya Adicipta Wisesa sebagai main dealer motor honda di Sulawesi Utara dan juga jaringan $\mathrm{H} 1$ (penjualan), $\mathrm{H} 2$ (pemeliharaan) dan H3(suku cadang) yang berada di Minahasa Utara.

\section{B. Populasi Penelitian}

Populasi dari penelitian ini adalah customer pengguna Website PT. Daya Adicipta Wisesa yang ada di Minahasa Utara, berdasarkan jaringan $\mathrm{H} 1$ (penjualan), $\mathrm{H} 2$ (pemeliharaan) dan $\mathrm{H} 3$ (suku cadang) yang berjumlah 1 main dealer, 2 dealer, dengan total 3 jaringan. Peneliti mendapatkan data customer berdasarkan data rata-rata perbulan untuk setiap jaringan yaitu, untuk PT. Daya Adicipta Wisesa mempunyai rata-rata customer per bulan sebanyak 400 customer, untuk Daya Motor mempunyai rata-rata customer per bulan sebanyak 200 customer dan untuk Mark Motor mempunyai rata-rata customer sebanyak 150 customer. Total keseluruhan populasi sebanyak 750 orang.

\section{Sampel Penelitian}

Tenik yang akan digunakan dalam pengambilan sampel yaitu dengan teknik Purposive Sampling, atau pengambilan sampel dengan menentukan terlebih dahulu kriteria dari setiap responden yang sudah pernah mengakses website tersebut. Dibawah ini merupakan rumus Slovin yang digunakan peneliti untuk menentukan berapa banyak jumlah sampel yang akan diambil, berikut ini adalah rumusnya:

$$
n=\frac{N}{1+N(e)^{2}}
$$

Keterangan: 
$n=$ Sampel

$N=$ Populasi

\section{$e=$ Nilai Presisi / batas kesalahan}

Dalam penggunaan rumus slovin pada penelitian ini menetapkan taraf keyakinan sebesar 90\% akan hasil kebenaran dan batas kesalahan sebesar 0,1 yang memastikan bahwa hanya $10 \%$ kesalahan yang akan terjadi. Perhitungan sampel penelitian yang didapatkan, menggunakan rumus Slovin, yaitu sebesar 88 responden. Hasil tersebut didapatkan dari jumlah populasi customer yang berada di 1 main dealer dan 2 jaringan PT. Daya Adicipta Wisesa dan didapatkan oleh peneliti populasinya sebesar 750 orang, kemudian dikalikan dengan batas kesalahan $\mathrm{e}=0,1$ yang dipangkatkan dua dan ditambah 1 , kemudian hasil yang didapatkan dibagi dengan jumlah populasi. Jadi, berdasarkan jumlah sampel yang didapatkan maka PT. Daya Adicipta Wisesa sebagai main dealer mendapatkan 30 kuesioner, Daya Motor mendapatkan 29 kuesioner dan Marks Motor mendapatkan 29 kuesioner dengan total semua 88 kuesioner.

\section{Kerangka Konseptual Penelitan}

Pada kerangka konseptual penelitian seperti pada Gambar 1, penulis memilih beberapa variable yang akan diteliti dan juga diuji. Beberapa variable yang mempengaruhi, diamati untuk mengetahui efeknya terhadap variabel yang dipengaruhi, yang disebut sebagai variabel akibat atau output. Variable usability, information quality dan service interaction merupakan variabel-variabel yang akan mempengaruhi tingkat kualitas dari kinerja website yang akan dirasakan saat ini serta kepentingan terhadap website tersebut, melalui pengukuran Importance Performance Analysis. Pada kerangka konseptual ini, peneliti memasukan metode IPA karena metode ini menjadi pengukuran utama dari analisis kualitas Website PT. Daya Adicipta Wisesa yang diukur berdasarkan tiga dimensi WebQual 4.0 yang nantinya akan memberikan hasil apakah pengguna merasa puas atau tidak terhadap kualitas Website PT. Daya Adicipta Wisesa.

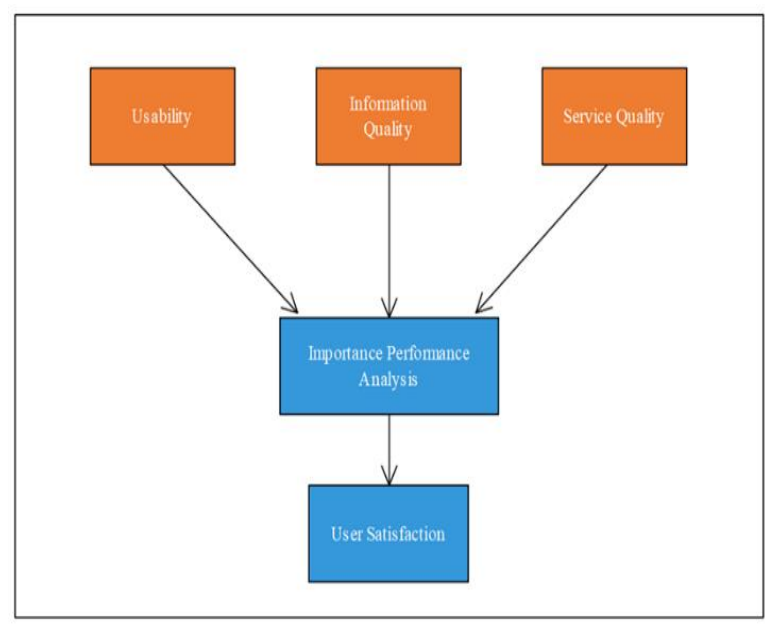

Gambar 1. Kerangka Konseptual Penelitian

\section{E. Desain Penelitian}

Dalam proses penyelesaian penelitian ini, berbagai rangkaian beserta proses atau tahapan dibuat peneliti untuk digunakan sebagai dasar penelitiannya, diantaranya, seperti yang terdapat dalam desain alur penelitian dan penjelasannya pada Gambar 2:

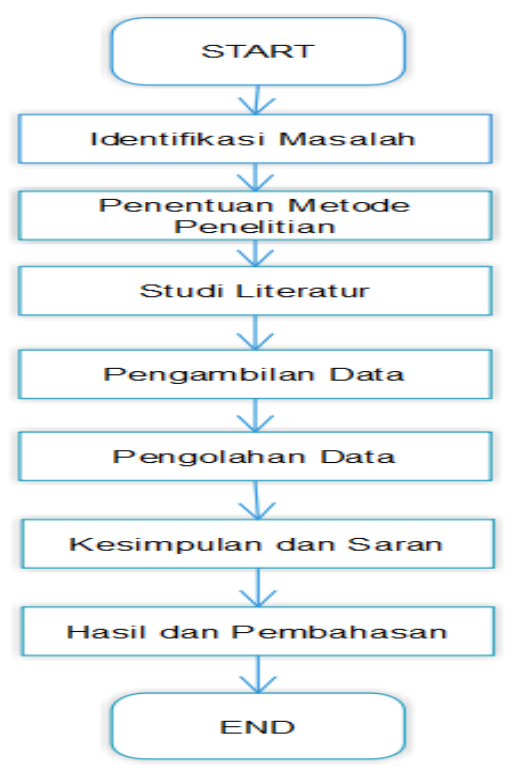

Gambar 2. Desain Alur Penelitian [15]

1) Pada tahap permulaan peneliti mengidentifikasi terlebih dahulu berbagai permasalahan PT. Daya Adicipta Wisesa, yaitu terdapat permasalahan dalam memberikan informasi kepada customer dan informasi yang kurang update. Dalam tahap identifikasi masalah, peneliti telah melakukan presentasi dan juga wawancara di PT. Daya Adicipta Wisesa untuk mendapatkan informasi

2) Setelah melakukan identifikasi pada permasalahan, peneliti mulai memilih metode yang memungkinkan untuk digunakan dalam mengatasi permasalahan dengan menggunakan solusi yang ada, yaitu dengan cara menggunakan metode deskriptif kualitatif sebagai prosedur penelitian yang menghasilkan data deskriptif berupa kata-kata tertulis atau lisan dari orang-orang dan perilaku yang dapat diamati.

3) Tahap selanjutnya yang akan dilakukan peneliti yaitu dengan melakukan studi literature pada penelitian dengan cara membaca buku-buku dan jurnal beserta artikel dari penelitian yang terkait mengenai metode Webqual 4.0 dan Importance Performance Analysis (IPA).

4) Pada tahap ini, dalam melakukan pengambilan data, peneliti membagikan kuesioner dengan menggunakan Google Form dan dibagikan kepada responden dimana jumlah banyaknya sesuai dengan sampel yang ada. 
5) Setelah melakukan pembagian kuesioner, tahap selanjutnya peneliti melakukan olah data berupa analisis kesenjangan (GAP), analisis kesesuaian, dan analisis kuadran, sesuai data yang telah diperoleh dari para responden melalui kuesioner.

6) Bagian ini melakukan pembahasan mengenai hasil dari kuesioner, yang akan memperlihatkan hasil kinerja beserta kepentingan dari website dan hasil dari pembahasan yang akan menunjukan prioritas masing-masing atribut yang diambil berdasarkan analisis kuadran.

7) Pada tahap terakhir ini, seluruh hasil kesimpulan dari penelitian akan memberikan masukan dan saran terhadap penelitian yang diteliti.

Metode yang digunakan dalam penelitian ini merupakan penelitian deskriptif kuantitatif. Penelitian deskriptif kuantitatif dideskripsikan dengan cara yang sistematis dan faktual, serta akurat dalam fakta tertentu yang nantinya akan memberikan jawaban serta informasi terhadap suatu masalah atau fenomena yang terjadi menggunakan pendekatan penelitian kuatitatif atau pendekatan yang dalam proses pengujiannya menggunakan angka-angka beserta statistic [14].

\section{HASIL DAN PEMBAHASAN}

Karakteristik dari responden yang terdapat pada penelitian ini menunjukan segmentasi usia yang dibagi berdasarkan klasifikasi usia menurut departemen kesehatan Indonesia yaitu, $77.27 \%$ berada diusia remaja akhir 17-25 tahun, $17.05 \%$ berada diusia dewasa awal 2635 tahun, 4.55\% untuk usia dewasa akhir 36-45 tahun, dan $1.14 \%$ lansia awal berada diusia 46-55 tahun. Selanjutnya dari karakteristik berdasarkan tempat tinggal yang dibagi berdasarkan kecamatan yang ada di Kabupaten Minahasa Utara yaitu, $21.59 \%$ berada di
Kecamatan Airmadidi. $20.45 \%$ berada di Kecamatan Kalawat, $12.50 \%$ berada di Kecamatan Kauditan dan $45.45 \%$ berada diluar Kabupaten Minahasa Utara. Berdasarkan hasil yang telah di analisa dari kuesioner yang sudah dibagikan kepada 88 responden dapat disimpulkan bahwa pengunjung dari website DAW yang paling tinggi adalah remaja akhir yang berada diusia 17 25 tahun dan berdasarkan tempat tinggal untuk wilayah Kabupaten Minahasa Utara mendapatkan hasil 54.54\% dan untuk wilayah diluar Kabupaten Minahasa Utara mendapatkan hasil $45.45 \%$ dari total 88 responden yang telah mengisi kuesioner.

\section{A. Perhitungan Kuesioner}

Tabel 1 dibawah ini, adalah hasil pembobotan nilai dari setiap atribut untuk nilai performance. Pembobotan dilakukan dengan cara, setiap jumlah responden yang mengisi setiap atribut dikalikan dengan masing-masing skala, dari skala 1 sampai 5 . Skala adalah perbandingan antar kategori dimana masing-masing kategori diberi bobot nilai yang berbeda, sedangkan skor adalah skor mentah yang telah diubah menjadi bentuk lain berdasarkan penyimpangannya dari harga mean dan dinyatakan dalam

satuan deviasi standar yang. Rumus untuk menghitung Nilai Performance adalah:

Total Skor $=$ Total skala $\mathrm{x}$ Angka skala

Hasil dari pembobotan nilai performance, ditunjukan pada skor, dan total skor adalah hasil penjumlahan dari setiap skor pada masing-masing skala. Kemudian untuk nilai rata-rata diambil dari jumlah skor yang dibagi dengan jumlah responden, dan hasil rata-rata secara keseluruhan dari nilai performance sebesar 3.674. Untuk hasil dari nilai performance akan digunakan pada analisis kuadran sebagai titik sumbu X.

TABEL I

PERHITUNGAN NILAI PERFORMANCE

\begin{tabular}{|c|c|c|c|c|c|c|c|c|c|c|c|c|}
\hline \multirow{3}{*}{ Atribut } & \multicolumn{10}{|c|}{ PERFORMANCE } & \multirow{3}{*}{$\begin{array}{l}\text { Total } \\
\text { Skor }\end{array}$} & \multirow{3}{*}{ Rata-rata } \\
\hline & \multicolumn{5}{|c|}{ Skala } & \multicolumn{5}{|c|}{ Skor } & & \\
\hline & 1 & 2 & 3 & 4 & 5 & 1 & 2 & 3 & 4 & 5 & & \\
\hline 1 & 0 & 10 & 24 & 29 & 25 & 0 & 20 & 72 & 116 & 125 & 333 & 3.78 \\
\hline 2 & 0 & 17 & 19 & 30 & 22 & 0 & 34 & 57 & 120 & 110 & 321 & 3.65 \\
\hline 3 & 0 & 10 & 24 & 28 & 26 & 0 & 20 & 72 & 112 & 130 & 334 & 3.8 \\
\hline 4 & 0 & 4 & 30 & 37 & 17 & 0 & 8 & 90 & 148 & 85 & 331 & 3.76 \\
\hline 5 & 0 & 15 & 23 & 36 & 14 & 0 & 30 & 69 & 144 & 70 & 313 & 3.56 \\
\hline 6 & 0 & 1 & 25 & 39 & 23 & 0 & 2 & 75 & 156 & 115 & 348 & 3.96 \\
\hline 7 & 0 & 3 & 33 & 31 & 21 & 0 & 6 & 99 & 124 & 105 & 334 & 3.8 \\
\hline 8 & 0 & 6 & 28 & 37 & 17 & 0 & 12 & 84 & 148 & 85 & 329 & 3.74 \\
\hline 9 & 2 & 10 & 28 & 32 & 16 & 2 & 20 & 84 & 128 & 80 & 314 & 3.57 \\
\hline 10 & 11 & 22 & 17 & 23 & 15 & 11 & 44 & 51 & 92 & 75 & 273 & 3.1 \\
\hline 11 & 1 & 15 & 13 & 35 & 24 & 1 & 30 & 39 & 140 & 120 & 330 & 3.75 \\
\hline 12 & 0 & 4 & 37 & 27 & 20 & 0 & 8 & 111 & 108 & 100 & 327 & 3.72 \\
\hline 13 & 0 & 0 & 23 & 44 & 21 & 0 & 0 & 69 & 176 & 105 & 350 & 3.98 \\
\hline 14 & 0 & 20 & 25 & 24 & 19 & 0 & 40 & 75 & 96 & 95 & 306 & 3.48 \\
\hline 15 & 0 & 17 & 22 & 30 & 19 & 0 & 34 & 66 & 120 & 95 & 315 & 3.58 \\
\hline 16 & 0 & 2 & 30 & 33 & 23 & 0 & 4 & 90 & 132 & 115 & 341 & 3.88 \\
\hline 17 & 6 & 27 & 21 & 18 & 16 & 6 & 54 & 63 & 72 & 80 & 275 & 3.13 \\
\hline 18 & 1 & 20 & 31 & 19 & 17 & 1 & 40 & 93 & 76 & 85 & 295 & 3.35 \\
\hline 19 & 0 & 18 & 30 & 5 & 35 & 0 & 36 & 90 & 20 & 175 & 321 & 3.65 \\
\hline 20 & 0 & 2 & 6 & 46 & 34 & 0 & 4 & 18 & 184 & 170 & 376 & 4.27 \\
\hline & & & & & $-\mathbf{R}$ & Sesel & & & & & & 3.67 \\
\hline
\end{tabular}


TABEL II

PERHITUNGAN NILAI IMPORTANCE

\begin{tabular}{|c|c|c|c|c|c|c|c|c|c|c|c|c|}
\hline \multirow{3}{*}{ Atribut } & \multicolumn{10}{|c|}{ IMPORTANCE } & \multirow{3}{*}{$\begin{array}{l}\text { Total } \\
\text { Skor }\end{array}$} & \multirow{3}{*}{ Rata-rata } \\
\hline & \multicolumn{5}{|c|}{ Skala } & \multicolumn{5}{|c|}{ Skor } & & \\
\hline & 1 & 2 & 3 & 4 & 5 & 1 & 2 & 3 & 4 & 5 & & \\
\hline 1 & 0 & 0 & 0 & 33 & 55 & 0 & 0 & 0 & 132 & 275 & 407 & 4.625 \\
\hline 2 & 0 & 0 & 6 & 42 & 40 & 0 & 0 & 18 & 168 & 200 & 386 & 4.386 \\
\hline 3 & 0 & 0 & 5 & 36 & 47 & 0 & 0 & 15 & 144 & 235 & 400 & 4.545 \\
\hline 4 & 0 & 0 & 3 & 35 & 50 & 0 & 0 & 9 & 140 & 250 & 403 & 4.58 \\
\hline 5 & 0 & 0 & 15 & 37 & 36 & 0 & 0 & 45 & 148 & 180 & 390 & 4.432 \\
\hline 6 & 0 & 3 & 16 & 39 & 30 & 0 & 6 & 48 & 156 & 150 & 366 & 4.159 \\
\hline 7 & 0 & 0 & 11 & 30 & 47 & 0 & 0 & 33 & 120 & 235 & 392 & 4.455 \\
\hline 8 & 0 & 0 & 21 & 36 & 31 & 0 & 0 & 63 & 144 & 155 & 381 & 4.33 \\
\hline 9 & 0 & 0 & 3 & 37 & 48 & 0 & 0 & 9 & 148 & 240 & 397 & 4.511 \\
\hline 10 & 0 & 0 & 2 & 43 & 43 & 0 & 0 & 6 & 172 & 215 & 393 & 4.466 \\
\hline 11 & 0 & 0 & 6 & 32 & 50 & 0 & 0 & 18 & 128 & 250 & 396 & 4.5 \\
\hline 12 & 0 & 0 & 16 & 34 & 38 & 0 & 0 & 48 & 136 & 190 & 374 & 4.25 \\
\hline 13 & 0 & 0 & 7 & 36 & 45 & 0 & 0 & 21 & 144 & 225 & 396 & 4.5 \\
\hline 14 & 0 & 0 & 9 & 48 & 31 & 0 & 0 & 27 & 192 & 155 & 383 & 4.352 \\
\hline 15 & 0 & 1 & 9 & 48 & 30 & 0 & 2 & 27 & 192 & 150 & 376 & 4.273 \\
\hline 16 & 0 & 0 & 6 & 37 & 45 & 0 & 0 & 18 & 148 & 225 & 393 & 4.466 \\
\hline 17 & 0 & 0 & 11 & 36 & 41 & 0 & 0 & 33 & 144 & 205 & 383 & 4.352 \\
\hline 18 & 0 & 0 & 8 & 52 & 28 & 0 & 0 & 24 & 208 & 140 & 384 & 4.364 \\
\hline 19 & 0 & 0 & 7 & 43 & 38 & 0 & 0 & 21 & 172 & 190 & 388 & 4.409 \\
\hline 20 & 0 & 0 & 3 & 38 & 47 & 0 & 0 & 9 & 152 & 235 & 396 & 4.5 \\
\hline & & & & & cata & 1 & & & & & & 4.423 \\
\hline
\end{tabular}

Data dalam Tabel 2 adalah hasil pembobotan dari nilai importance, yang nantinya akan digunakan pada analisis kuadran sebagai titik potong sumbu Y. Dimana rata-rata keseluruhan dari nilai importance adalah 4.423.

\section{B. Indentifikasi Masalah}

Dalam tahap ini peneliti akan mengukur perbandingan skor important dan skor performance, untuk melihat seberapa besar kepuasan customer dalam penggunaan website daw. Rumus yang digunakan untuk menghitung tingkat kesesuaian adalah:

$T k i=\frac{x i}{y i} \times 100 \%$

Keterangan:

Tki $=$ Hasil Kesesuaian

$\mathrm{Xi}=$ Skor dari Penilaian Kinerja

$\mathrm{Yi}=$ Skor dari Penilaian Kepentingan

Pada penelitian ini perbandingan antara total skor dari setiap atribut untuk nilai performance dan importance yang selanjutnya didapatkan hasil persentasi tingkat kesesuaian

dari setiap atribut, dan untuk nilai rata-rata keseluruhan tingkat kesesuaian sebesar $84.23 \%$. Dari hasil yang telah ada dapat disimpulkan bahwa kualitas website kurang atau tidak memenuhi apa yang dianggap penting oleh pengguna website daw.

\section{Analisis Kesenjangan (GAP)}

Analisis Kesenjangan (GAP) merupakan suatu metode pengukuran untuk mengetahui kesenjangan (GAP) antara kinerja suatu variabel dengan kepentingan terhadap variable tersebut. Pada tahap ini peneliti akan menghitung nilai GAP dari setiap atribut dari rata-rata skor nilai kinerja dan skor nilai kepentingan. Rumus yang digunakan untuk mencari nilai kesenjangan (GAP) adalah:
Qi $=$ Performance $i$ - Importance $i$ (4)

Keterangan:

Qi $=$ Tingkat GAP

Performance i = Skor nilai Kinerja

Importance $\mathrm{I}=$ Skor nilai Kepentingan

Nilai kesenjangan (GAP) pada penelitian ini adalah 0.734 nilai positif akan diperoleh apabila skor kinerja lebih besar dari skor kepentingan sedangkan apabila skor kepetingan lebih besar daripada skor kinerja akan diperoleh nilai kesenjangan (GAP) Negative. Semakin tinggi skor kepentingan dan semakin rendah skor kinerja, berarti nilai kesenjangan (GAP) semakin besar. Apabila total nilai kesenjangan (GAP) positif maka pengguna dianggap merasa sangat puas terhadap website. Sebaliknya bila nilai kesenjangan (GAP) Negative, maka pengguna kurang atau tidak puas terhadap website yang ada.

\section{Analisis Kuadran}

Analisis Kuadran adalah suatu bangun yang dibagi empat bagian yang dibatasi oleh dua buah garis yang berpotongan tegak lurus pada $\left(\mathrm{x}^{-}, \mathrm{y}\right)$ dimana $\mathrm{x}^{-}$merupakan rata-rata dari rata-rata skor performance dan y ${ }^{-}$merupakan rata-rata dari rata-rata skor important. Untuk menerapkan analisis kuadran yaitu dengan menghitung rata-rata skor importance dan performance. Berdasarkan perhitungan yang diperoleh bahwa untuk nilai rata-rata dari rata-rata skor performance $x^{-}$adalah 3.674 dan rata-rata skor importance $y^{-}$adalah 4.423 . Selanjutnya skor rata-rata dari hasil penilaian tingkat performance dan tingkat importance akan diplotkan ke dalam diagram kartesius seperti pada gambar 3 berikut. 


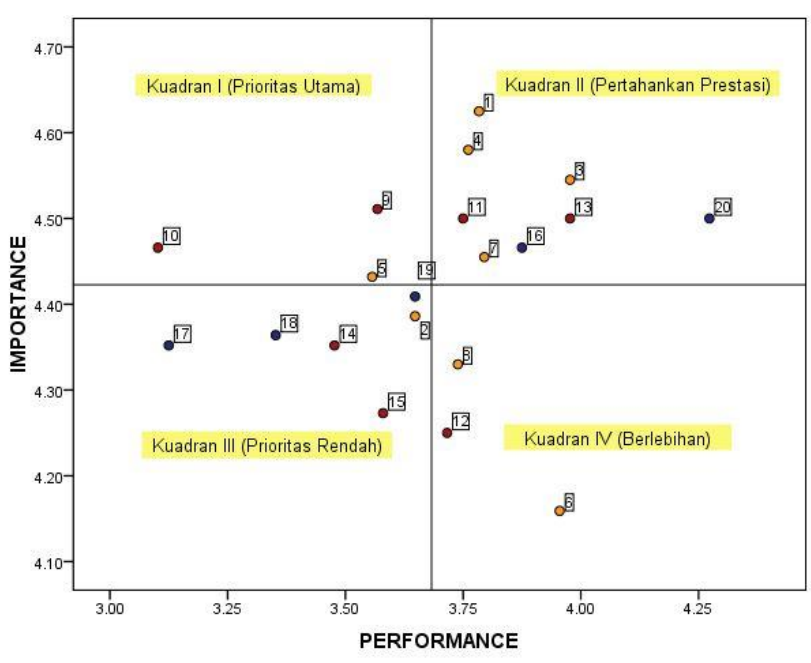

Gambar 3. Diagram Kartesius

Keterangan:

Usability

Information Quality

Service Interaction

Penjelasan dari hasil analisis kuadran pada diagram kartesius diatas yang dibagi menjadi 4 kuadran sebagai berikut:

\section{1) Kuadran I (Prioritas Utama)}

Merupakan tingkat pengukuran yang dianggap penting oleh pengguna namun kinerjanya rendah sehingga perlu segera ditingkatkan. Beberapa atribut pada website tersebut adalah:

a. Atribut nomor 5 yaitu, website daw tidak mempunyai desain yang menarik.

b. Atribut nomor 9 yaitu, informasi yang ada pada website daw tidak akurat. Informasi yang ada pada website daw tidak akurat.

c. Atribut nomor 10 yaitu, informasi yang ada pada website daw tidak up to date.

\section{2) Kuadran II (Pertahankan Prestasi)}

Merupakan tingkat pengukuran kualitas yang harus dipertahankan kinerjannya karena, tingkat kinerja serta kepentingannya sama-sama tinggi yang artinya, para pengguna merasa sangat penting untuk tetap mempertahankan kualitas kinerja dari setiap atribut pada website. Beberapa atribut tersebut adalah:

a. Atribut nomor 1 yaitu, website daw mudah diperlajari dan dioperasikan.

b. Atribut nomor 3 yaitu, website daw mudah untuk digunakan.

c. Atribut nomor 4 yaitu, saya mudah mencari informasi dalam website daw.

d. Atribut nomor 7 yaitu, website daw tampak meyakinkan dan kompeten.

e. Atribut nomor 11 yaitu, informasi yang ada pada website daw dapat diepercaya.

f. Atribut nomor 13 yaitu, informasi yang ada pada website daw mudah untuk dimengerti. g. Atribut nomor 16 yaitu, website daw mempunyai reputasi yang baik.

h. Atribut nomor 20 yaitu, website daw memberikan layanan sesuai dengan apa yang disajikan.

3) Kuadran III (Prioritas Rendah)

Merupakan pengukuran kualitas yang memiliki prioritas rendah, importance dan performance sama-sama rendah, yang artinya pengguna merasa kinerja setiap atribut kurang, tapi untuk dilakukan perbaikan tidak terlalu diprioritaskan. Beberapa website tersebut antara lain:

a. Atribut nomor 2 yaitu, interaksi dari website daw kurang jelas dan kurang bisa dimengerti.

b. Atribut nomor 14 yaitu, Informasi yang ada pada website daw kurang memberikan informasi yang tepat.

c. Atribut nomor 15 yaitu, Informasi yang ada pada website daw kurang memberikan informasi yang sesuai.

d. Atribut nomor 17 yaitu, website daw tidak mempunyai bot chat yang membantu dalam bertanya.

e. Atribut nomor 18 yaitu, saya merasa mudah untuk berkomunikasi dengan pihak perusahaan melalui nomor telepon dan email yang ada pada website daw.

f. Atribut nomor 19 yaitu, pihak perusahaan kurang memberikan jawaban yang baik dan cepat ketika saya bertanya melalui telepon.

4) Kuadran IV (Berlebihan)

Merupakan tingkat pengukuran kualitas yang dianggap berlebihan Tindikarenakan tingkat kinerja pada website sangat tinggi tetapi dari segi kepentingannya, para pengguna tidak merasa penting mengenai perbaikan atribut tersebut. Beberapa atribut dalam website tersebut adalah sebagai berikut:

a. Atribut Atribut nomor 6 yaitu, desain dari website daw sesuai dengan tipe website pada umumnya.

b. Atribut nomor 8 yaitu, website daw memberikan kesan positif bagi saya.

c. Atribut nomor 12 yaitu, informasi yang ada pada website daw relevan.

\section{KESIMPULAN}

Berdasarkan hasil yang telah dapat dari kuesioner yang sudah dibagikan kepada 88 responden dapat disimpulkan bahwa pengunjung dari website DAW yang paling tinggi adalah remaja akhir yang berada diusia $17-$ 25 tahun dan berdasarkan tempat tinggal untuk wilayah Kabupaten Minahasa Utara mendapatkan hasil 54.54\% dan untuk wilayah diluar Kabupaten Minahasa Utara mendapatkan hasil $45.45 \%$. Tingkat kesesuaian yang menunjukan perbandingan total skor antara importance dan performance dari setiap atribut menampilkan hasil yang kurang dari $100 \%$. Sistem ini memiliki 4 user seperti Administrator, Operator, Alumni, dan Pengguna Lulusan. Dimana setiap user memiliki hak akses yang berbeda-beda. Analisis kesenjangan (GAP), menghasilkan nilai rata-rata -0.734. Hasil dari analisis kuadran untuk prioritas utama adalah: Website daw tidak mempunyai desain yang menarik, informasi yang ada pada website daw tidak akurat. Berdasarkan hasil tersebut maka tujuan penelitian 
ini dapat dicapai dalam menanalisi layanan website PT. Daya Adicipta Wisesa dengan menggunakan metode WebQual 4.0 dan Importance Performance Analysis (IPA)

\section{DAFTAR PUSTAKA}

[1] D. O. Soemantri, "(Studi Kasus: CV. Zamrud Multimedia Network)," vol. 2, no. 1, p. 7, 2016.

[2] APJII, "Asosiasi Penyelenggara Jasa Internet Indonesia," Jan. 2019.

[3] E. S. Indri Endang Lestari, "Analisis dan Pemanfaatan Website Universitas Esa Unggul Jakarta," Universitas Binadarma, Palembang, 2012.

[4] D. B. Napitupulu, "Evaluasi Kualitas Website Universitas XYZ Dengan Pendekata Webqual [Evaluation of XYZ University Website Quality Based on Webqual Approach]," Bul. Pos Dan Telekomun., vol. 14, no. 1, p. 51, Jul. 2016, doi: 10.17933/bpostel.2016.140105

[5] S. Monalisa, "Analisis Kualitas Layanan Website Terhadap Kepuasan Mahasiswa dengan Penerapan Metode Webqual (Studi Kasus: UIN Suska Riau)," vol. 13, p. 9, 2016.

[6] E. C. I. Azizah, H. Aryadita, and A. D. Herlambang, "Evaluasi Kualitas Website Forum Diskusi Online Menggunakan Metode Webqual 4.0 dan Importance Performance Analysis (Studi Kasus Pada Website Dictio)," p. 11.

[7] L. Nasution, I. Aknuranda, and A. Rachmadi, "Evaluasi Situs Web Pemerintah Menggunakan Metode Webqual Dan Importance-Performance Analysis (IPA) (Studi Kasus: Situs Kecamatan Lowokwaru-Malang)," p. 8

[8] H. Juhanda and P. K. Sari, "Analisis Kualitas Website Jalur Nugraha Ekakurir (JNE) menggunakan pendekatan Webqual dan Importance Performance Analaysis (IPA) menurut persepsi Online Seller," p. 8.

[9] R. Husaini, M. Suyanto, and E. T. Luthfi, "Evaluasi Web Sekolah SMK Muhammadiyah 1 Banatul menggunakan Metode Webqual \& Importance Performance Analysis," p. 10, 2017.

[10] S. J. Barnes and R. T. Vidgen, "An Integrative Approach to the Assessment of E-Commerce Quality," vol. 3, no. 3, p. 14, 2002.

[11] "PT.Daya Adicipta Wisesa." http://daya-wisesa.com.

[12] J. R. Soeprapto and M. Kuning, "Analisis Kualitas Layanan Website SIKMB menggunakan Metode Webqual 4.0 (Studi Pada BP Batam)," vol. 06, p. 15, 2019.

[13] Muhsin Nur Ali, "Pengukuran Kualitas Wesbite UIN Suan Kalijaga Menggunakan Metode Webqual 4.0," 2017, p. 171.

[14] B. S. Santoso and M. F. Anwar, "Analisis Kualitas Website menggunakan Metode Webqual dan Importance Performance Analysis (IPA) pada situs Kaskus," p. 8.

[15] Tri Rizqi Ariantoro, "MENGUKUR KUALITAS WEBSITE DENGAN METODE WEBQUAL (STUDI KASUS : STIK BINA HUSADA PALEMBANG)," vol. VI, no 1, Jun. 2017. 